\title{
Short-term effects of nereid polychaete size and density on sediment inorganic nitrogen cycling under varying oxygen conditions
}

\author{
Jennifer A. Bosch*, Jeffrey C. Cornwell, W. Michael Kemp \\ University of Maryland Center for Environmental Science, Horn Point Laboratory, 2020 Horns Point Rd, Cambridge, \\ MD 21613-0775, USA
}

\begin{abstract}
Chronic eutrophication and expanding seasonal hypoxia $\left(\mathrm{O}_{2}<63 \mu \mathrm{M}\right)$ in estuaries like Chesapeake Bay have altered benthic faunal communities in favor of opportunistic species that can quickly populate organic-rich sediments following hypoxic events. It has been suggested that the biogenic activity of polychaetes can stimulate microbial ammonification, nitrification, and/or denitrification in estuarine sediments as well as increase the fluxes of inorganic nitrogen $\left(\mathrm{NH}_{4}{ }^{+}, \mathrm{NO}_{2}{ }^{-}, \mathrm{NO}_{3}{ }^{-}, \mathrm{N}_{2}\right)$ across the sediment-water interface. Results of 2 laboratory experiments with the opportunistic polychaete Alitta (Neanthes) succinea were used to quantify the short-term influence of density and size of surface-feeding polychaetes on denitrification and sedimentwater fluxes of inorganic nitrogen under varying oxygen conditions. This study shows that polychaete enhancements of $\mathrm{O}_{2}$ and nitrogen fluxes were strongly correlated with total animal biomass. Fluxes of $\mathrm{O}_{2}, \mathrm{NH}_{4}{ }^{+}$and $\mathrm{N}_{2}$ were stimulated by presence of animals for both larger and smaller worms, but per capita effects were greater for the deep-burrowing larger polychaetes. With the onset of hypoxic conditions, all density treatments had reductions in $\mathrm{O}_{2}, \mathrm{NH}_{4}{ }^{+}$and $\mathrm{N}_{2}$ fluxes, with the high-density treatment showing the greatest change. Denitrification efficiency was $33 \%$ higher for experiments with large worms than for smaller worm treatments, suggesting that the former were more effective in removing fixed nitrogen.
\end{abstract}

KEY WORDS: Polychaetes - Nitrogen cycling - Sediment biogeochemistry · Bioirrigation · Hypoxia $\cdot$ Denitrification $\cdot$ Alitta succinea

\section{INTRODUCTION}

The complex biological, chemical, and physical processes in coastal sediments play an important, often seasonally varying, role in the functioning of healthy productive estuaries (Bianchi 2007). Early diagenesis of organic material in sediments, which involves a series of biochemical processes mediated by microbes, is influenced by the bioturbation activity of polychaete worms and other benthic macrofauna. This bioturbation has been observed to affect the cycling of nitrogen (Welsh 2003). While the topic of benthic faunal bioturbation has been widely studied, many questions remain unresolved about how different animals directly and indirectly affect sediment biogeochemistry and sediment matrices (Meysman et al. 2006, Kristensen et al. 2012).

In many estuaries, benthic communities are under stress from expanding and intensifying hypoxia (Diaz \& Rosenberg 2008). In Chesapeake Bay, summertime hypoxia $\left(\mathrm{O}_{2}<63 \mu \mathrm{M}\right)$ is a common occurrence in response to large inputs of algal bloom organic material that sinks to the bottom (Officer et al. 1984). Over the past 4 decades, increased seasonal hypoxia in estuaries such as Chesapeake Bay has altered the structure of the entire ecosystem (Kemp et al. 2005), shifting benthic macrofaunal communities to favor opportunistic species. In many cases, these species 
are polychaete worms that are resistant to short-term oxygen $\left(\mathrm{O}_{2}\right)$ limitation (Diaz \& Rosenberg 1995). Depending on feeding type (subsurface deposit-, surface deposit-, or suspension-feeder), polychaetes of different size and abundance have varying effects on organic matter diagenesis and associated nutrient and solute exchanges with the overlying water (Schaffner et al. 2001, Kristensen \& Kostka 2005).

In areas experiencing short-term hypoxic events, the maintenance of opportunistic polychaete populations can mitigate some of the biogeochemical impacts of reduced oxygen, allowing an ecosystem to maintain healthy nutrient remineralization cycles (Gray et al. 2002, Welsh 2003). Observations show that some nereid polychaetes are able to switch from aerobic to anaerobic respiration during periods of $\mathrm{O}_{2}$ limitation (Jørgensen \& Kristensen 1980, Kristensen 1983a). Recolonization of sediments by these animals, after a defaunating hypoxic event, tends to alter sediment biogeochemistry in ways that differ from those associated with mature benthic systems (Nizzoli et al. 2007). Few studies have explored the transitional biogeochemical effects of sediment colonization by opportunistic polychaetes following large disturbances associated with hypoxia or other drastically altered conditions (Bartoli et al. 2000, Nizzoli et al. 2007).

While polychaete worms are among the most pervasive benthic macrofauna in estuarine systems, their role in sediment biogeochemical processes has been characterized for surprisingly few species (Kristensen \& Kostka 2005). Much of that work has involved 2 nereid worms, Nereis (Neanthes) virens and Nereis (Hediste) diversicolor (Diaz \& Rosenberg 1995, Kristensen 2000, Kristensen et al. 2012). Influences of these polychaetes on sediment biogeochemical processes tend to be variable due to differences in feeding and bioirrigation behaviors (Kristensen 1983a,b, Papaspyrou et al. 2006). Alitta (Neanthes) succinea is a versatile species common to North American estuarine systems, with facultative deposit- and suspension-feeding habits (Jørgensen \& Kristensen 1980, Miron \& Kristensen 1993). Indeed, A. succinea is an opportunistic worm that can both withstand temporary hypoxia and repopulate defaunated areas following major perturbations (Kristensen 1983a). Biogeochemical effects of $A$. succinea's bioturbation activities have, however, not been well described (Fauchald \& Jumars 1979, Holland et al. 1987, Llanso et al. 2002).

This study expands on previous research by examining short-term effects of $A$. succinea abundance, biomass, and size on sediment-water fluxes of $\mathrm{O}_{2}$ and nitrogen solutes under aerobic, transitional, and hypoxic conditions. Rates of $\mathrm{O}_{2}, \mathrm{NH}_{4}{ }^{+}, \mathrm{NO}_{3}{ }^{-}$(plus $\mathrm{NO}_{2}{ }^{-}$), and $\mathrm{N}_{2}$ fluxes were measured for triplicate experimental systems, and vertical profiles of porewater $\mathrm{NH}_{4}{ }^{+}$and bromide-tracer concentrations were also measured to quantify responses to treatments. This study was designed to test the following 2 working hypotheses: (1) polychaete enhancement of net inorganic nitrogen fluxes and sediment $\mathrm{O}_{2}$ consumption are functions of total macrofaunal biomass, and these sediment-water fluxes will change as overlying water $\mathrm{O}_{2}$ is decreased from aerobic to hypoxic levels; and (2) under aerobic conditions the polychaete enhancements of these sediment-water fluxes are greater for systems with larger worms.

\section{MATERIALS AND METHODS}

\section{Sediment sampling and preparation}

The Choptank River estuary is a tributary system of Chesapeake Bay whose watershed covers 1756 km² (Fisher et al. 2006). All sediment samples were collected from a nearshore cove located in the mesohaline region of the Choptank estuary (salinity 8-10) in 1-2 $\mathrm{m}$ of water with soft, muddy sediment (Porter et al. 2006).

For each incubation experiment, the sediment was defaunated using one of 2 different methods (see below) followed by a minimum of $2 \mathrm{wk}$ submerged in a chemostat-like equilibration system. This system consisted of a greenhouse tank equipped with an inflow of unfiltered Choptank estuary water. A standpipe in the outflow allowed for the tank water height to be maintained covering the defaunated cores. The tank was loosely covered with a Styrofoam board to maintain shade and prevent algal growth, and $\mathrm{O}_{2}$ was maintained near saturation using aquarium bubblers.

In the first experiment, sediments were collected by hand coring with acrylic cylinders $(6.5 \mathrm{~cm}$ diameter, $30.5 \mathrm{~cm}$ length). Sample cores were then defaunated by capping the cores with rubber stoppers and placing them in the dark for $12 \mathrm{~h}$ to induce anoxia. After that time, the top $10 \mathrm{~cm}$ of sediment was removed from each core along with the macrofauna that had migrated toward the surface in response to low $\mathrm{O}_{2}$ treatment (Porter et al. 2006). In the second experiment, sediments were sieved using a 500- $\mu \mathrm{m}$ sieve to remove infauna and larger material; the sediment slurry was then allowed to settle in 6 buckets (20 l). After $12 \mathrm{~h}$ of settling, the sediments 
were equilibrated using the same flow-through system described above. These sediments were allowed to equilibrate for $\sim 30 \mathrm{~d}$ before being sub-cored with the acrylic cylinders.

\section{Effects of polychaete abundance and oxygen (Expt A-O)}

Expt A-O measured effects of changing $\mathrm{O}_{2}$ levels on sediment-water flux of nitrogen and $\mathrm{O}_{2}$ under different abundances of polychaetes $(2$ to $6 \mathrm{~cm}$ resting length). Individual $A$. succinea polychaetes were collected from Choptank oyster reef samples maintained in an oyster hatchery. All collected worms were immediately sorted into 2 size (resting length) categories - small $(1.0-4.9 \mathrm{~cm})$ and large $(5.0-14.0 \mathrm{~cm})$ - and placed in specimen dishes containing aerated estuarine water. Worms were added to sediment cores in triplicate for 2 polychaete abundance categories (Table 1) - low abundance (5 ind. core ${ }^{-1}$ including 1 large and 4 small worms) and high abundance (11 ind. core $^{-1}$ including 3 large and 8 small worms), where experimental low and high abundance levels were equivalent to $\sim 1500$ and 3300 worms $\mathrm{m}^{-2}$, respectively. These experimental abundances compare well with historical summer densities of polychaetes in the Choptank estuary, which range from $\sim 500$ to 4000 worms $\mathrm{m}^{-2}$ (Llanso et al. 2010) and to the worm densities used in previous published experiments (e.g. Bartoli et al. 2000, Swan et al. 2007). Cores were then allowed to equilibrate overnight in cylindrical tanks filled with estuarine water under continuous aeration and water circulation in a dark, temperature-controlled $\left(25^{\circ} \mathrm{C}\right)$ chamber at ambient salinity (11.4). After $12 \mathrm{~h}$ of equilibration, all exper- imental cores, including sediment-free water blank cores, were sealed without bubbles, with an O-ring fitted top with sampling valves. Cores were arranged around a central magnetic stirring motor that turned magnetic stirrers in each core at rates below the threshold of sediment resuspension (Kana et al. 2006).

The sediment incubations were carried out over $28 \mathrm{~h}$, to allow continuous $\mathrm{O}_{2}$ depletion to hypoxic levels. Visual observations of worm behavior in each core were recorded and water samples were taken from each chamber at $2 \mathrm{~h}$ intervals for the first $12 \mathrm{~h}$. Three final samples were collected at 20, 24, and $28 \mathrm{~h}$. At each sampling point, $\sim 30 \mathrm{ml}$ of water was collected by gravity flow through valves in the core tops. The replacement water that refilled each core at sampling was collected from the Choptank estuary when cores were moved to the incubation chamber. Water samples were filtered using a $25 \mathrm{~mm}$ diameter, $0.45 \mu \mathrm{m}$ cellulose acetate syringe filter (Nalgene \#191-2045) into vials and frozen for analyses of ammonium $\left(\mathrm{NH}_{4}^{+}\right)$, and nitrate-plus-nitrite (hereafter referred to as nitrate or $\mathrm{NO}_{\mathrm{x}}$ ). Dissolved gas samples were collected in $\sim 7 \mathrm{ml}$ ground glass stoppered test tubes that were filled with a dip tube; samples were preserved with $10 \mu \mathrm{l}$ of $50 \%$ saturated mercuric chloride $\left(\mathrm{HgCl}_{2}\right)$ solution. Dissolved gas samples were held under water at ambient bottom water temperatures until analysis.

The incubation was divided into 3 phases based on overlying water $\mathrm{O}_{2}$ concentrations: (1) aerobic $\left(\mathrm{O}_{2}>\right.$ $94 \mu \mathrm{M}) ;(2)$ transition (64-93 $\mu \mathrm{M} \mathrm{O}_{2}$ ); and (3) hypoxic $\left(\mathrm{O}_{2}<63 \mu \mathrm{M}\right)$. The duration and onset of the transition phase varied between treatments depending on the number of polychaetes added to each core. Overlying water in the high and low abundance cores was hypoxic in approx. 8 and $18 \mathrm{~h}$, respectively. Solute

Table 1. Worm-addition study design details for both abundance-size (A-S) and abundance-oxygen (A-O) experiments. Mean total dry weights per core were measured post experiment (small worms $=\mathrm{S}$, large worms $=\mathrm{L}$ ). Expt A-O polychaetes experienced anoxia between 6 and $15 \mathrm{~h}$ after the start of the $24 \mathrm{~h}$ incubation depending on the size and density of treatments

\begin{tabular}{|c|c|c|c|c|c|c|}
\hline $\begin{array}{l}\text { Treatment } \\
\text { added core }^{-1}\end{array}$ & $\begin{array}{c}\text { No. } \\
\text { worms }\end{array}$ & $\begin{array}{l}\text { Worm density } \\
\text { (ind. } \mathrm{m}^{-2} \text { ) }\end{array}$ & $\begin{array}{c}\text { Mean } \\
\text { length }(\mathrm{cm})\end{array}$ & $\begin{array}{c}\text { Mean dry mass } \\
\left(\mathrm{g} \mathrm{m}^{-2}\right)\end{array}$ & $\begin{array}{l}\text { Incubation } \\
\text { temp. }\left({ }^{\circ} \mathrm{C}\right)\end{array}$ & $\begin{array}{l}\text { Incubation } \\
\text { salinity }\end{array}$ \\
\hline \multicolumn{7}{|c|}{ Expt A-O (24 h incubation) } \\
\hline Control & 0 & - & - & - & \multirow{3}{*}{25.0} & \multirow{3}{*}{11.4} \\
\hline Low biomass & 5 & 1515 & 2.7 & 1.96 & & \\
\hline High biomass & 11 & 3333 & 3.0 & 11.63 & & \\
\hline \multicolumn{7}{|c|}{ Expt A-S (6 h incubation) } \\
\hline Control & 0 & - & - & - & \multirow{4}{*}{$15.0(\mathrm{~S}), 19.8(\mathrm{~L})$} & \multirow{4}{*}{$9.9(\mathrm{~S}), 9.0(\mathrm{~L})$} \\
\hline Large worm only & 1 & 303 & 10.5 & $22.1(\mathrm{~L})$ & & \\
\hline Low biomass & 4 & 1212 & 3.2 & $15.32(\mathrm{~S}), 158.32(\mathrm{~L})$ & & \\
\hline High biomass & 8 & 2424 & 8.5 & $26.70(\mathrm{~S}), 171.70(\mathrm{~L})$ & & \\
\hline
\end{tabular}


fluxes were calculated for aerobic, transition, and hypoxic phases. Following experiments, all recovered worms were dried and weighed (Table 1).

\section{Effects of polychaete abundance and size (Expt A-S)}

Expt A-S measured short-term (3 to $6 \mathrm{~h}$ ) effects of different-sized (small and large) polychaetes on the sediment-water fluxes of $\mathrm{O}_{2}$ and nitrogen at different worm densities. As described for Expt A-O, A. succinea individuals were immediately sorted by size and placed in specimen dishes and then transferred to sediment cores in triplicate at densities of 4 and 8 worms per core (Table 1). Due to equipment availability large and small worm treatments were run in separate incubations (Parts 1 and 2, respectively). During the incubations, visual observations of worm behavior were recorded and overlying water was sampled every $1.5 \mathrm{~h}$. Overlying water $\mathrm{O}_{2}$ conditions remained aerobic for the duration of the incubations for all treatments except in the high-abundance large worm treatments, which approached hypoxia after $\sim 3$ h. For these latter cores, however, only flux rates during the aerobic portion of the incubation were used in our analysis.

To estimate how polychaete size influenced the relative contribution of direct worm excretion to total $\mathrm{NH}_{4}{ }^{+}$flux, we compared calculated rates for cores with large and small worms. Specifically, we con- trasted rates (Table 2) for duplicate cores with 1 large worm (mean biomass $=166 \mathrm{~g}$ wet weight $\mathrm{m}^{-2}$ ) with triplicate cores containing 8 small worms (mean total biomass $=194 \mathrm{~g}$ wet weight $\mathrm{m}^{-2}$ ). These cores were incubated concurrently and experienced the same temperatures and pre-incubation sediment treatments. We used an allometric relationship for nereid worms (Table 2) to calculate excretion, $V=0.27 W^{0.62}$, where $W$ is individual wet weight (Kristensen 1984).

\section{Sediment-water gas and solute flux analysis}

Ratios of gas concentrations $\left(\mathrm{O}_{2}: \mathrm{N}_{2}\right.$ and $\mathrm{N}_{2}$ :Ar $)$ were measured using a membrane inlet mass spectrometer (MIMS) calibrated with an air-saturated standard (Kana et al. 1994). Nitrate was analyzed via segmented flow analysis after cadmium (Cd) reduction and ammonium was manually analyzed with a phenylhypochlorite colorimetric technique (Parsons 1984). Sediment flux rates of solutes were calculated based on the change in solute concentration over the duration of the incubations. Blank core incubations (water-only) had only minor changes in solute concentration over the incubation periods. Corrections were made to account for water column effects when significant linear changes in the blank were observed for an analyte. We did not correct for replacement water additions because mean differences with and without corrections were small $(<2 \%)$. Statistical analyses of these data were performed using SAS

Table 2. Calculated polychaete excretion contribution to ammonium flux at different size and biomasses. All worms added to incubations were recovered except in the large worm high-density treatment, where the average number of worms recovered was 5 instead of 8

\begin{tabular}{|c|c|c|c|c|c|c|c|}
\hline Worm density & $\begin{array}{c}\text { Worm } \\
\text { biomass } \\
\left(\mathrm{g} \mathrm{WW} \mathrm{m}^{-2}\right)^{\mathrm{a}}\end{array}$ & $\begin{array}{c}\text { Total } \mathrm{NH}_{4}^{+} \text {flux } \\
(\mathrm{mmol} \\
\left.\mathrm{m}^{-2} \mathrm{~h}^{-1}\right)^{\mathrm{b}}\end{array}$ & $\begin{array}{c}(\mathrm{mmol} \\
\left.\text { worm }^{-1} \mathrm{~h}^{-1}\right)^{\mathrm{c}}\end{array}$ & $\frac{(\mathrm{mmol}}{\left.\operatorname{core}^{-1} \mathrm{~h}^{-1}\right)^{\mathrm{d}}} \mathrm{N}$ & $\begin{array}{l}{ }^{+} \text {excretion } \\
(\mathrm{mmol} \\
\left.\mathrm{m}^{-2} \mathrm{~h}^{-1}\right)^{\mathrm{e}}\end{array}$ & $\begin{array}{c}(\mathrm{mmol} \\
\left.\mathrm{g}^{-1} \mathrm{~h}^{-1}\right)^{\mathrm{f}}\end{array}$ & $\%$ Total flux ${ }^{g}$ \\
\hline \multicolumn{8}{|l|}{ Small worms } \\
\hline Low & 95 & 263 & 0.07 & 0.29 & 86 & 0.91 & 33 \\
\hline High & 194 & 337 & 0.07 & 0.58 & 175 & 0.90 & 52 \\
\hline \multicolumn{8}{|l|}{ Large worms } \\
\hline Low & 986 & 665 & 0.31 & 1.23 & 374 & 0.38 & 56 \\
\hline High & 2344 & 738 & 0.34 & 1.72 & 520 & 0.35 & 71 \\
\hline 1 worm & 166 & 343 & 0.24 & 0.24 & 73 & 0.43 & 21 \\
\hline $\begin{array}{l}{ }^{\mathrm{a}} \text { Mean biomass } \\
{ }^{\mathrm{b}} \text { Mean total am } \\
\text { (Kristensen } 19 \\
{ }^{\mathrm{c} E x c r e t i o n} \text { rate } \\
{ }^{\mathrm{d}} \text { Excretion rate } \\
{ }^{\mathrm{e}} \text { Excretion rate } \\
{ }^{\mathrm{f}} \text { Excretion rate } \\
{ }^{\mathrm{g}} \text { Excretion rate }\end{array}$ & $\begin{array}{l}\text { f triplicate cor } \\
\text { honium flux exc } \\
\text { 4) } \\
\text { ased on the me } \\
\text { er } \mathrm{m}^{2} \text { for each } \\
\text { er gram wet w } \\
\text { ased as a perce }\end{array}$ & $\begin{array}{l}\text { es } \\
\text { cretion rates }(V) \text { c } \\
\text { ean weight of the } \\
\text { plied by the numb } \\
\text { treatment } \\
\text { eight of worm } \\
\text { entage of the tota }\end{array}$ & $\begin{array}{l}\text { calculated base } \\
\text { worms recove } \\
\text { ber of worms re }\end{array}$ & $\begin{array}{l}\text { d on } V=0.27 \\
\text { ed from core } \\
\text { covered from }\end{array}$ & $\begin{array}{l}0.62, \text { where } \\
\text { ter incubati } \\
\text { ach core }\end{array}$ & biomass ( & wet weight) \\
\hline
\end{tabular}


v.9.2 statistical software. One-way or 2-way mixed model ANOVAs with repeated measures and a Tukey-Kramer multiple comparison test were used to test for significant differences $(p<0.05)$ in responses to treatments for both experiments. To understand treatment effects on the balance between $\mathrm{NH}_{4}$ flux and denitrification ( $\mathrm{N}_{2}$ flux), an index of 'denitrification efficiency' (DE) was calculated for each density treatment in each experiment. Here we define DE as $100\left[\left(\mathrm{~N}_{2}\right.\right.$ flux $) /\left(\mathrm{N}_{2}\right.$ flux $+\mathrm{NO}_{\mathrm{x}}$ flux $+\mathrm{NH}_{4}{ }^{+}$flux $\left.)\right]$.

\section{Bromide tracer diffusion model}

Upon completing incubations in Expt A-S , 8 mM sodium bromide $(\mathrm{NaBr})$ was added to the overlying water of experimental cores, which were continuously aerated and stirred at constant temperature. After $24 \mathrm{~h}$, cores were sliced into vertical sections $(1 \mathrm{~cm})$, and sediments were placed into $50 \mathrm{ml}$ centrifuge tubes. Porewater was centrifuged at $2000 \times g$, filtered $(0.2 \mu \mathrm{m})$, and frozen for subsequent $\mathrm{Br}$ and $\mathrm{NH}_{4}{ }^{+}$analysis. Porewater $\mathrm{Br}$ concentrations were measured using a Dionex ICS 2000 ion chromatograph, and $\mathrm{NH}_{4}{ }^{+}$was diluted (20:1) and measured as above.

A simple model was used to compute effective diffusion of the $\mathrm{Br}$ ion tracer in pore waters for each treatment. Changes in vertical distribution of Br concentration $(C)$ were computed iteratively across the $1 \mathrm{~cm}$ vertical sections of the sample cores over $24 \mathrm{~h}$ using Fick's First Law of diffusion: $J_{\mathrm{s}}=-\varphi D_{\mathrm{s}}(\mathrm{d} C / \mathrm{d} X)$, where $J_{\mathrm{s}}$ is the flux ( $\mathrm{mol} \mathrm{cm} \mathrm{cm}^{-2} \mathrm{~s}^{-1}$ ), $\varphi$ is porosity, $D_{\mathrm{s}}$ is the molecular diffusion coefficient of $\operatorname{Br}\left(\mathrm{cm}^{-2} \mathrm{~s}^{-1}\right)$, and $\mathrm{d} C / \mathrm{d} X$ the concentration gradient $\left(\mathrm{mol} \mathrm{Br} \mathrm{cm}^{-4}\right.$ ). Temperature and initial $\mathrm{Br}$ concentrations were set according to experimental conditions, and values for $D_{\mathrm{s}}$ in sediments were estimated as $D_{\mathrm{s}}=D_{\mathrm{sw}} / \theta$, where $D_{\text {sw }}$ is the molecular diffusion coefficient of $\mathrm{Br}\left(\mathrm{cm}^{-2}\right.$ $\mathrm{s}^{-1}$ ) in seawater at the respective experiment temperature (Yuan-Hui \& Gregory 1974) and tortuosity $(\theta)$ calculated as $\theta^{2}=1-\ln \left(\varphi^{2}\right)$ (Boudreau 1996). These model values were compared to measured $\mathrm{Br}$ values in experimental core sediments.

\section{RESULTS}

\section{Incubation conditions}

Within an hour after addition to experimental cores, all polychaetes had completed burrows and initiated ventilation, both of which were observed through transparent acrylic core walls. After overnight equilibration, redox effects of ventilation were already evident as the vivid reddish-brown coloration of burrows contrasting with the ambient black mud and reflecting the oxidization of reduced iron. When experimental $\mathrm{O}_{2}$ conditions decreased from aerobic to hypoxic, polychaetes migrated to the sediment surface and burrow ventilation activity declined. In some instances for cores with higher worm density treatments, a few polychaetes swam into the inflow supply tubes or escaped out of the core via the outflow tubes, in which case they were captured and weighed. For Expt A-S, solute fluxes were calculated only for the aerobic portion of the incubation, while Expt A-O fluxes were computed for aerobic, transitional and hypoxic portions of the incubation.

\section{Sediment fluxes of oxygen and nitrogen species (Expt A-O)}

Under the aerobic phase of the experiment, the addition of $A$. succinea significantly increased sediment $\mathrm{O}_{2}$ demand, with the most significant increase in the high-density treatment (ANOVA, p < 0.05) (Fig. 1A). Aerobic $\mathrm{NH}_{4}{ }^{+}$efflux in the high-density treatment was significantly greater $(p<0.003)$ than in the other treatments (Fig. 1B); however, fluxes for control and low-density treatments were not significantly different from each other $(p>0.96)$. Although effluxes of $\mathrm{NO}_{\mathrm{x}}$ were observed in the control and low-density treatments, $\mathrm{NO}_{\mathrm{x}}$ uptake occurred in high-density treatments (Fig. 1C). Denitrification rates under aerobic conditions, as measured with $\mathrm{N}_{2}$ efflux ( $\mu$ mol $\mathrm{N}_{2}-\mathrm{N} \mathrm{m}^{-2} \mathrm{~h}^{-1}$ ), were increased by 3 -fold higher $(\mathrm{p}<0.05)$ for high-density worm abundance compared to the controls and low-density treatments (Fig. 1D).

As overlying water $\mathrm{O}_{2}$ concentrations declined from aerobic to transitional to hypoxic conditions, solute fluxes generally decreased. For example, $\mathrm{O}_{2}$ flux (sediment $\mathrm{O}_{2}$ demand) in the high-density treatment declined by $40 \%(\mathrm{p}<0.05)$ during the 'transition' phase and was reduced to $<10 \%$ of aerobic rates with hypoxia onset (Fig. 1A), and rates in the control and low-density treatments were only slightly lower through the transition but were reduced to $<20 \%$ of aerobic rates $(\mathrm{p}<0.05)$. Although $\mathrm{NH}_{4}{ }^{+}$fluxes were low for control and low-density treatments, they increased slightly as $\mathrm{O}_{2}$ levels declined from aerobic to hypoxic conditions, and the increase in rates was significant for control systems (Fig. 1B). In contrast, $\mathrm{NH}_{4}{ }^{+}$efflux rates for high-density treatments de- 

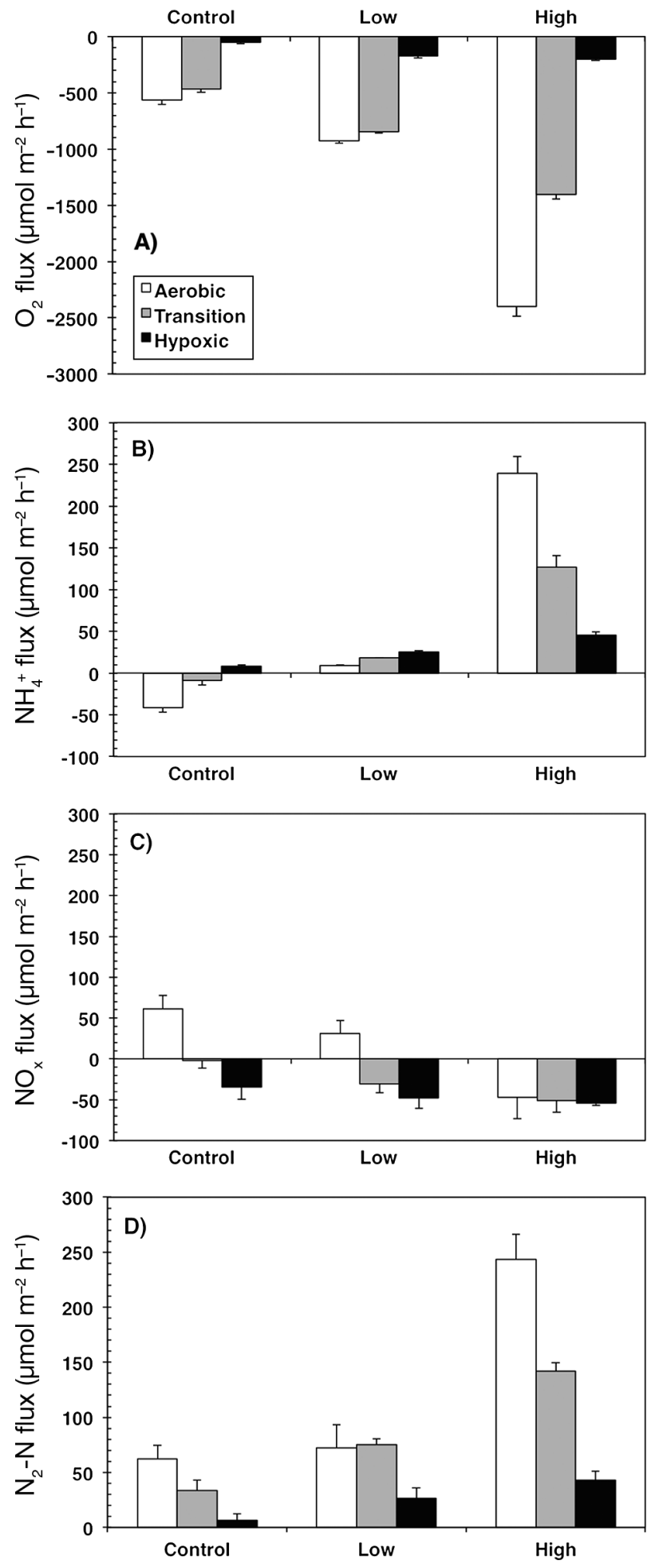

Fig. 1. Alitta succinea. Sediment-water solute fluxes measured over $24 \mathrm{~h}$ in core incubations in the abundance-oxygen (A-O) experiment (mean $\pm \mathrm{SE}, \mathrm{n}=3$ ) for: $(\mathrm{A}) \mathrm{O}_{2}$, (B) $\mathrm{NH}_{4}{ }^{+}$, (C) $\mathrm{NO}_{\mathrm{x}}$ and (D) $\mathrm{N}_{2}-\mathrm{N}$. The 3 primary treatments included control (no worms), low density (5 worms), and high-density (11 worms). At each density, results of $3 \mathrm{O}_{2}$ treatments are also shown: aerobic (>94 $\left.\mu \mathrm{M} \mathrm{O}_{2}\right)$, transition $\left(64-93 \mu \mathrm{M} \mathrm{O}_{2}\right)$, and hypoxic $\left(<63 \mu \mathrm{M} \mathrm{O}_{2}\right)$ creased significantly by $\sim 50$ and $60 \%$ from aerobic to transitional to hypoxic conditions. $\mathrm{NO}_{\mathrm{x}}$ fluxes for controls and low-density treatments declined from effluxes to influxes as $\mathrm{O}_{2}$ conditions deteriorated from aerobic to hypoxic, while small influxes remained unchanged across the $\mathrm{O}_{2}$ gradient for high-density treatments (Fig. 1C). Denitrification rates decreased significantly for control, low-density and highdensity treatments as oxygen declined significantly $(p<0.05)$ from aerobic to hypoxic conditions (Fig. 1D). A decline in $\mathrm{N}_{2}$ fluxes followed the gradual shift from aerobic to transition to hypoxic conditions for control and high-density treatments, whereas the decline in flux rates was more abrupt for the lowdensity treatment when $\mathrm{O}_{2}$ reached hypoxia.

A comparison of DE for worm density treatments suggests that DE values were higher for low-density polychaete treatments (Table 3 ). In addition, there was a marked decline in DE for low-density treatments, as $\mathrm{O}_{2}$ levels decreased from aerobic to transition to hypoxic conditions. In contrast, the high-density treatments maintained a modest $\mathrm{DE}$ level of $\sim 50 \%$ across all $\mathrm{O}_{2}$ levels.

\section{Sediment fluxes of oxygen and nitrogen species (Expt A-S)}

As in Expt A-O, the addition of A. succinea worms to sediment cores in Expt A-S resulted in significantly increased $(\mathrm{p}<0.05)$ sediment $\mathrm{O}_{2}$ and $\mathrm{NO}_{\mathrm{x}}$ influxes, as well as $\mathrm{NH}_{4}{ }^{+}$and $\mathrm{N}_{2}$ effluxes (Fig. 2, Table 3). Influx of $\mathrm{O}_{2}$ in low- and high-density treatments increased significantly by $>2.5$ - and 4 -fold, respectively, compared to the control treatment. $\mathrm{NH}_{4}{ }^{+}$flux increased with polychaete density for small worms and large worms; however, differences between low- and high-density treatments were significant ( $p<0.02)$ only for large worms (Fig. 2B). Mean rates of $\mathrm{NO}_{\mathrm{x}}$ influx were not different from controls for small worm treatments, but rates for large worm treatments were significantly different from controls for both low- and high-density worm additions (Fig. 2C). Denitrification rates were significantly increased $(p<0.05)$ with worm addition at both densities and worm sizes (Fig. 2D); however, $\mathrm{N}_{2}$ fluxes were not different between low- and highdensity for either size worms.

For the treatment with 1 large worm, $\mathrm{O}_{2}$ and nitrogen fluxes were significantly less $(p<0.05)$ than rates for the high-density large worm treatment but were not different from controls or low-density treatments (Table 3). Mean polychaete biomass levels for the 

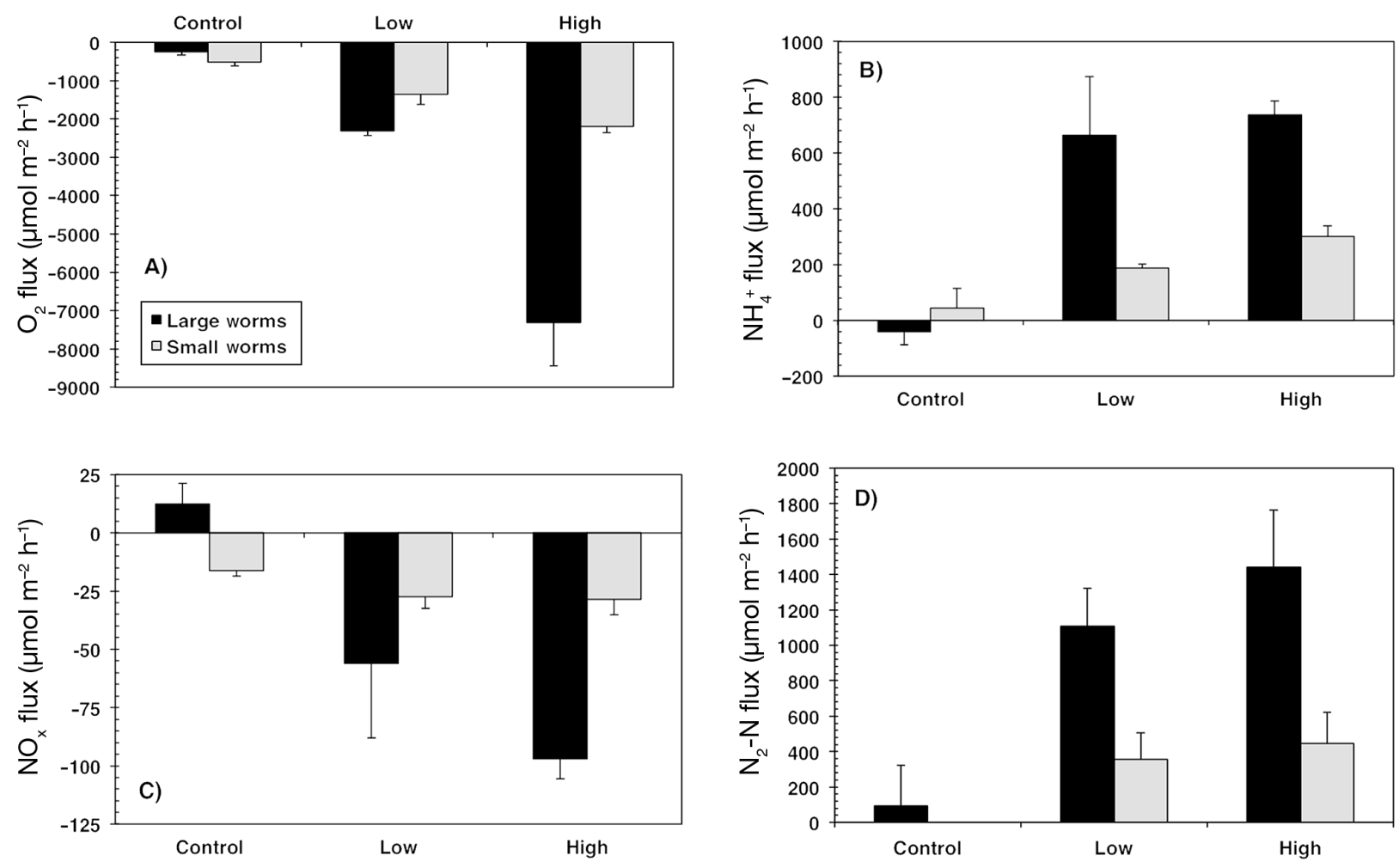

Fig. 2. Alitta succinea. Sediment-water solute fluxes measured over $6 \mathrm{~h}$ in core incubations in the abundance-size (A-S) experiment (mean $\pm \mathrm{SE}, \mathrm{n}=3$ ) for: $(\mathrm{A}) \mathrm{O}_{2},(\mathrm{~B}) \mathrm{NH}_{4}{ }^{+}$, (C) $\mathrm{NO}_{\mathrm{x}}$, and (D) $\mathrm{N}_{2}-\mathrm{N}$. Treatments include a sediment control (no worms), low-density (4 worms), and high-density ( 8 worms). At each density, results of 2 categories of worm size are also shown: small worm $(1-4.9 \mathrm{~cm})$ and large worms $(5-14 \mathrm{~cm})$ treatments

Table 3. Calculated solute fluxes and denitrification efficiency (DE), where all values represent mean of each treatment and are expressed in $\mu \mathrm{mol} \mathrm{m} \mathrm{m}^{-2} \mathrm{~h}^{-1}$. DE was calculated as $\% \mathrm{~N}_{2}-\mathrm{N}$ of total $\mathrm{NH}_{4}{ }^{+}$plus $\mathrm{NO}_{\mathrm{x}}$ plus $\mathrm{N}_{2}-\mathrm{N}$ fluxes

\begin{tabular}{|c|c|c|c|c|c|c|}
\hline Treatment & Worm density & $\begin{array}{l}\mathrm{NH}_{4} \\
\text { flux }\end{array}$ & $\begin{array}{l}\mathrm{NO}_{\mathrm{x}} \\
\text { flux }\end{array}$ & $\begin{array}{l}\mathrm{N}_{2}-\mathrm{N} \\
\text { flux }\end{array}$ & $\begin{array}{c}\mathrm{O}_{2} \\
\text { flux }\end{array}$ & $\begin{array}{l}\mathrm{DE} \\
(\%)\end{array}$ \\
\hline \multicolumn{7}{|l|}{ Expt A-O } \\
\hline \multirow[t]{3}{*}{ Oxic } & Control & -42 & 61 & 62 & 564 & - \\
\hline & Low $\left(5\right.$ core $\left.^{-1}\right)$ & 9 & 31 & 72 & 924 & 64 \\
\hline & High (11 core co $\left.^{-1}\right)$ & 225 & -47 & 243 & 2399 & 58 \\
\hline \multirow[t]{3}{*}{ Transition } & Control & -9 & -2 & 34 & 467 & - \\
\hline & Low $\left(5\right.$ core $\left.^{-1}\right)$ & 19 & -30 & 75 & 845 & 119 \\
\hline & High $\left(11\right.$ core $\left.^{-1}\right)$ & 127 & -51 & 142 & 1402 & 65 \\
\hline \multirow[t]{3}{*}{ Hypoxic } & Control & 8 & -34 & 7 & 52 & - \\
\hline & Low $\left(5\right.$ core $\left.^{-1}\right)$ & 25 & -48 & 27 & 174 & 614 \\
\hline & High (11 core $\left.^{-1}\right)$ & 46 & -54 & 43 & 199 & 123 \\
\hline \multicolumn{7}{|l|}{ Expt A-S } \\
\hline \multirow[t]{3}{*}{ Small worms } & Control & 142 & -16 & 0 & 521 & - \\
\hline & Low $\left(4\right.$ core $\left.^{-1}\right)$ & 188 & -27 & 355 & 1363 & 69 \\
\hline & High (8 core $^{-1}$ ) & 302 & -29 & 456 & 2196 & 63 \\
\hline \multirow[t]{4}{*}{ Large worms } & Control & -41 & 12 & 94 & 171 & - \\
\hline & 1 worm & 343 & -13 & 269 & 704 & 45 \\
\hline & Low $\left(4\right.$ core $\left.^{-1}\right)$ & 665 & -56 & 1108 & 2316 & 65 \\
\hline & High $\left(8\right.$ core $\left.^{-1}\right)$ & 738 & -97 & 1443 & 7323 & 69 \\
\hline
\end{tabular}

1 large worm treatment were $194 \mathrm{~g}$ wet $\mathrm{m}^{-2}$, which are significantly different from mean biomasses in control and large worm treatments, but are not different from values for the highdensity small worm treatment (166 g wet $\mathrm{m}^{-2}$ ). Mean $\mathrm{NH}_{4}{ }^{+}$effluxes for 1 large worm $\left(343 \mu \mathrm{mol} \mathrm{m}{ }^{-2} \mathrm{~h}^{-1}\right)$ and high-density small worm $(337 \mu \mathrm{mol}$ $\mathrm{m}^{-2} \mathrm{~h}^{-1}$ ) treatments were also not statistically different from each other. Thus, although mean values for polychaete biomass and $\mathrm{NH}_{4}^{+}$effluxes were $14 \%$ lower and $2 \%$ higher, respectively, 1 large worm treatment values were not significantly different from those for the high-density small worm treatment (Table 2).

Logistic constraints caused the timing of small and large worm phases of Expt A-S to be separated by $20 \mathrm{~d}_{\text {; }}$ however, comparison of sediment- 
water fluxes in the respective control treatment cores represents a measure of how different experimental conditions were between the 2 phases of this experiment. Mean fluxes of $\mathrm{O}_{2}$ and $\mathrm{N}_{2}$ were both directed into sediments for both small and large worm controls, and while rates for the large worm controls were $50 \%$ lower for $\mathrm{O}_{2}$ and $20 \%$ higher for $\mathrm{N}_{2}$ compared to small worm controls, these differences were not significant. $\mathrm{NH}_{4}{ }^{+}$and $\mathrm{NO}_{\mathrm{x}}$ fluxes were also not significantly different for large and small worm controls.

\section{Vertical profiles of pore water solute concentration}

The mean bromide porewater profiles for each treatment in Expt A-S exhibited clear patterns, comparing model-calculated profiles with those measured for the control, small worm and large worm treatments (Fig. 3). These profiles reflect differences in 'effective depth' of solute distributions as influenced by polychaetes of different size. The control treatments closely followed the molecular diffusion model profile. Compared to controls, small worm bromide profiles showed enhanced diffusion to a depth of $\sim 4.5 \mathrm{~cm}$. large worm bromide profiles reflect further enhanced diffusion to the bottom of the core $(12 \mathrm{~cm})$. In fact, at the end of the experiment, large worms were observed moving at the bottom edges of the core.

Porewater $\mathrm{NH}_{4}{ }^{+}$profiles of control treatments in small and large worm incubations showed increasing concentrations with depth (Fig. 4). For the small worm treatments, vertical profiles of $\mathrm{NH}_{4}{ }^{+}$did not appear to be substantially different between controls and treatments; however, the absence of replicate cores precludes testing for statistical significance among all treatments. In contrast, the vertical profiles of $\mathrm{NH}_{4}{ }^{+}$in large worm treatments were sampled in triplicate, and these mean profiles were markedly different for controls compared to worm treatments. Below $4.5 \mathrm{~cm}$ control cores had significantly higher $(p=0.008) \mathrm{NH}_{4}{ }^{+}$concentrations than did high- or low-density large worm cores, while above $4.5 \mathrm{~cm}$ depth, the high-density cores had significantly higher $(p=0.03)$ concentrations compared to controls.

\section{Biomass and N-cycling processes}

Major sediment N-cycling processes across both experiments show a strong linear relationship between biomass and measured $\mathrm{N}$ and $\mathrm{O}$ fluxes (Fig. 5). Additionally, measured or inferred by mass-balance

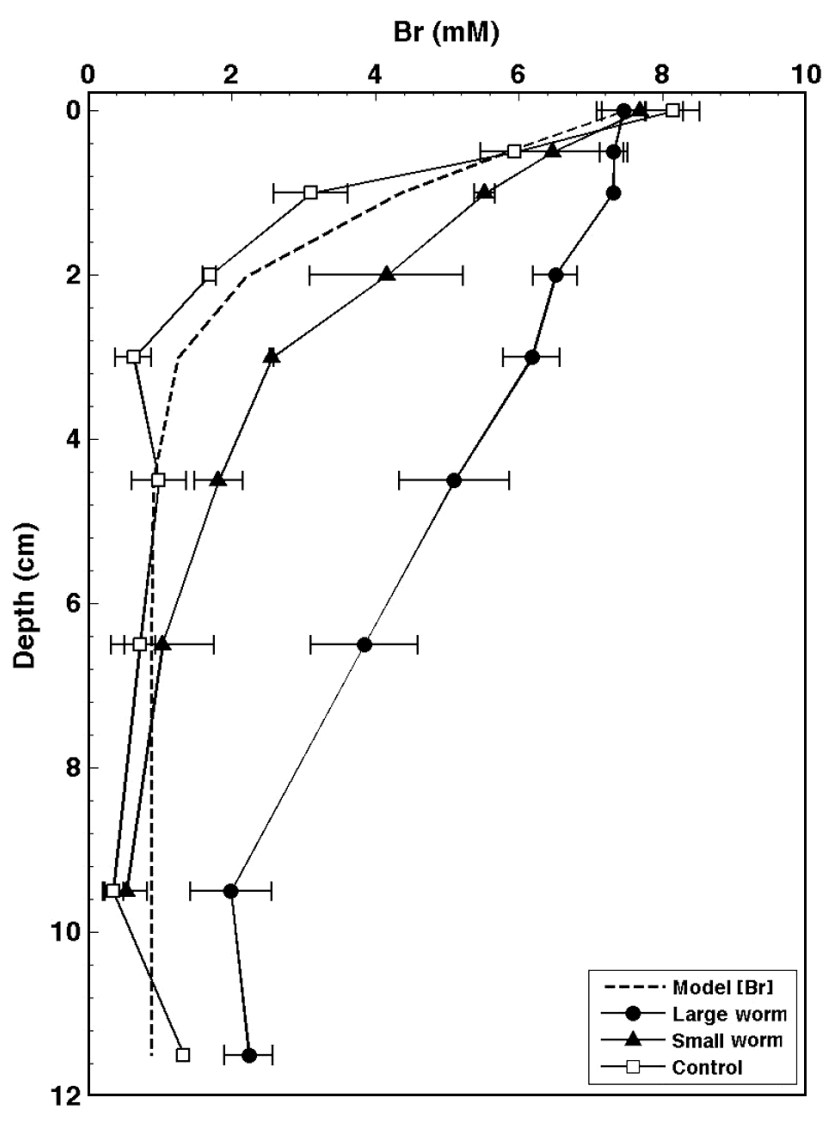

Fig. 3. Alitta succinea. Bromide (Br) distribution (mean $\pm \mathrm{SE}$, $\mathrm{n}=3$ ) in the abundance-size (A-S) experiment showing large worm, small worm, and control treatments. Dashed line represents a diffusion model based on Fick's First Law adjusted for the background $\mathrm{Br}$ concentration

calculations (Table 3, Fig. 6) compare mean $\mathrm{N}$ fluxes and transformation processes for high-density large (Fig. 6A) and small worm (Fig. 6B) treatments and for mean control (Fig. 6C) systems. For all processes, control rates were very low, compared to those for large and small worm treatments, with measured denitrification rates increasing more than 10-fold from control to small worm treatments and by $\sim 3$-fold from small to large worm treatments. On the other hand, calculated rates of net nitrification (denitrification - nitrate influx) increased by $~ 500$-fold from control to small worm and again by $\sim 5$-fold from small to large worm treatments (Fig. 6).

\section{DISCUSSION}

\section{Effects on sediment N-cycling of Polychaetes}

Sediment-water fluxes of $\mathrm{O}_{2}, \mathrm{NH}_{4}{ }^{+}$, and $\mathrm{N}_{2}$ consistently increased with the addition of the polychaete 

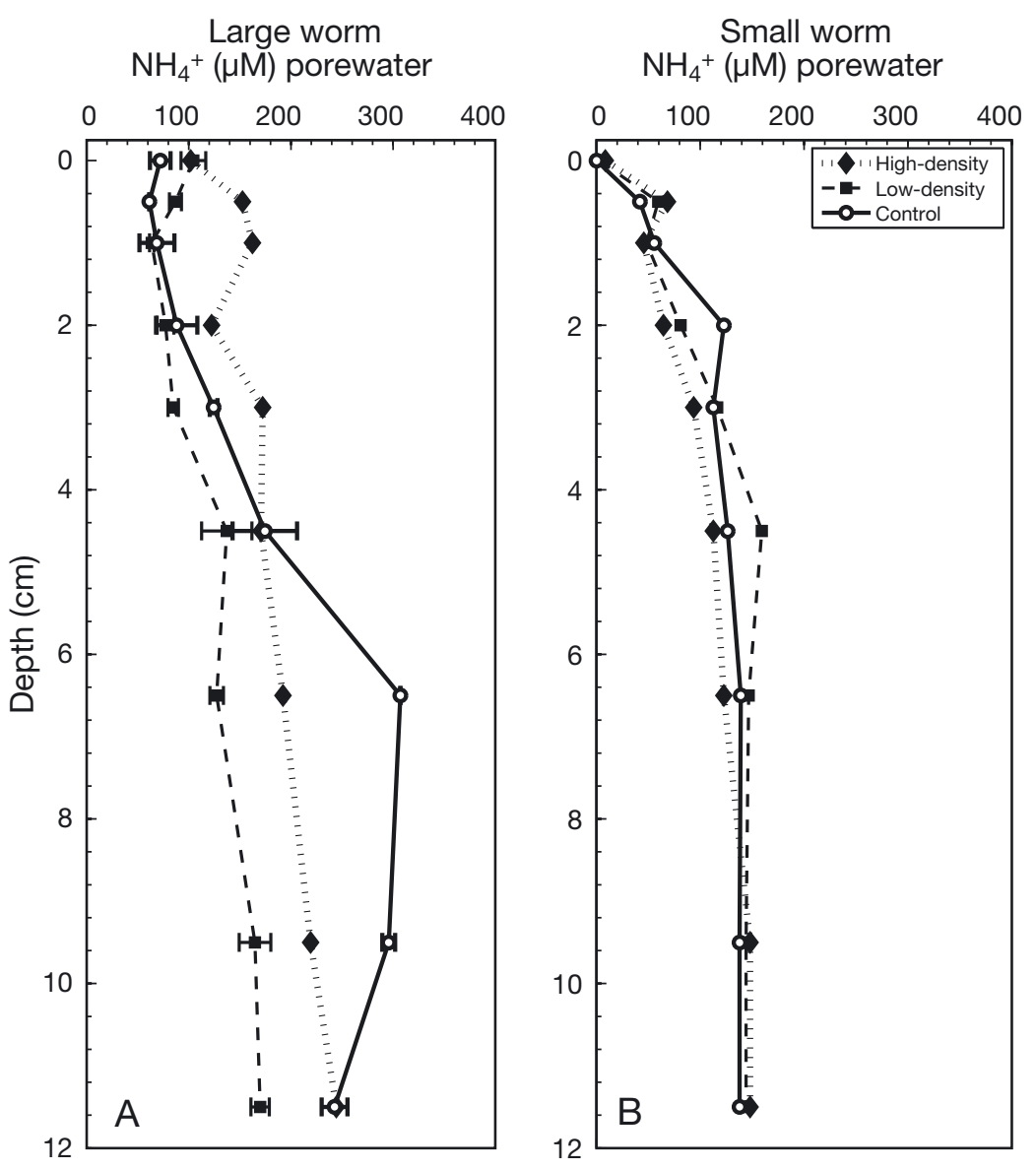

Fig. 4. Alitta succinea. Porewater $\mathrm{NH}_{4}{ }^{+}$concentration (mean $\pm 1 \mathrm{SE}, \mathrm{n}=3$ ) in the abundance-size (A-S) experiment showing (A) large worm and (B) small worm treatments. In both panels, high-density, low-density, and control treatments are presented. Standard errors were computed for all depths, but for clarity, bars are plotted here only for large worm control and low-abundance treatments

Alitta succinea, and these responses can be attributed to several biological and chemical mechanisms. These polychaete worms alter nitrogen fluxes through many processes including: (1) direct $\mathrm{NH}_{4}{ }^{+}$excretion; (2) stimulated microbial decomposition of organic material $_{i}(3)$ enhanced nitrification and coupling to denitrification by ventilating $\mathrm{O}_{2}$ into deep anoxic sediments; and (4) liberation of porewater $\mathrm{NH}_{4}^{+}$from deep sediments to overlying water. It appears that the shortterm responses to worm addition measured in this study may have involved all but the second of these mechanisms (Bartoli et al. 2000). Regardless of the mechanisms, our experiments revealed strong linear relationships of polychaete abundance and biomass to $\mathrm{NH}_{4}{ }^{+}, \mathrm{O}_{2}$ and $\mathrm{N}_{2}$ fluxes across the sediment-water interface (Figs. 1, $2 \& 5$ ). These effects of polychaete activity were most likely attributable to (1) increases in surface area separating oxidized and reduced sediments; (2) increased porewater circulation; and (3) solute transport through deep animal burrows (Aller 1994). $\mathrm{NO}_{\mathrm{x}}$ fluxes across the sediment-water interface were relatively small but highly variable, presumably because these fluxes resulted from the sum of diverse redox processes (Henriksen et al. 1983, Nizzoli et al. 2007) including nitrification, assimilation, denitrification, anammox and dissimilatory nitrate reduction to ammonium. In most instances, however, the magnitude and direction of $\mathrm{NO}_{\mathrm{x}}$ fluxes were directly related to overlying water column $\mathrm{NO}_{\mathrm{x}}$ levels (Kristensen 1984).

The enhancement of nitrification and denitrification with the addition of $A$. succinea was illustrated in both Expts A-O and A-S. $\mathrm{N}_{2}$ effluxes were significantly stimulated with worm additions in all experiments, but particularly with addition of deep-burrowing large polychaetes (Figs. 1-3). Similar measured $\mathrm{N}_{2}$ effluxes have been shown to be directly related to denitrification rates (e.g. Kana et al. 1994, An et al. 2001). Most measured $\mathrm{N}_{2}$ fluxes ranged between 50 and $300 \mu \mathrm{mol} \mathrm{m} \mathrm{m}^{-2} \mathrm{~h}^{-1}$ (Fig. 5), but a few rates exceeded $1000 \mu \mathrm{mol} \mathrm{m}{ }^{-2} \mathrm{~h}^{-1}$, rates that are similar to previously reported high values in Chesapeake Bay (Kellogg et al. 2013, 2014). Although the present study did not directly measure nitrification and its coupling to denitrification, massbalance calculations suggest that sediment nitrification drove the vast majority ( $90 \%$ ) of denitrification in these experiments (Fig. 6). While it is unlikely that nitrifier abundance grew substantially during these short experiments (Pelegri \& Blackburn 1995, Bartoli et al. 2000), it has been shown that 'dormant' nitrifiers in marine sediments tend to be rapidly revived and metabolizing when moved to new habitats with ideal growth conditions (Henriksen \& Kemp 1988). In addition, experimental polychaetes may also have inadvertently inoculated their burrows with active nitrifying microbes from surface sediment.

\section{Effects of polychaete biomass versus size}

When considering relationships between benthic macrofauna sediment-water fluxes of ecologically 

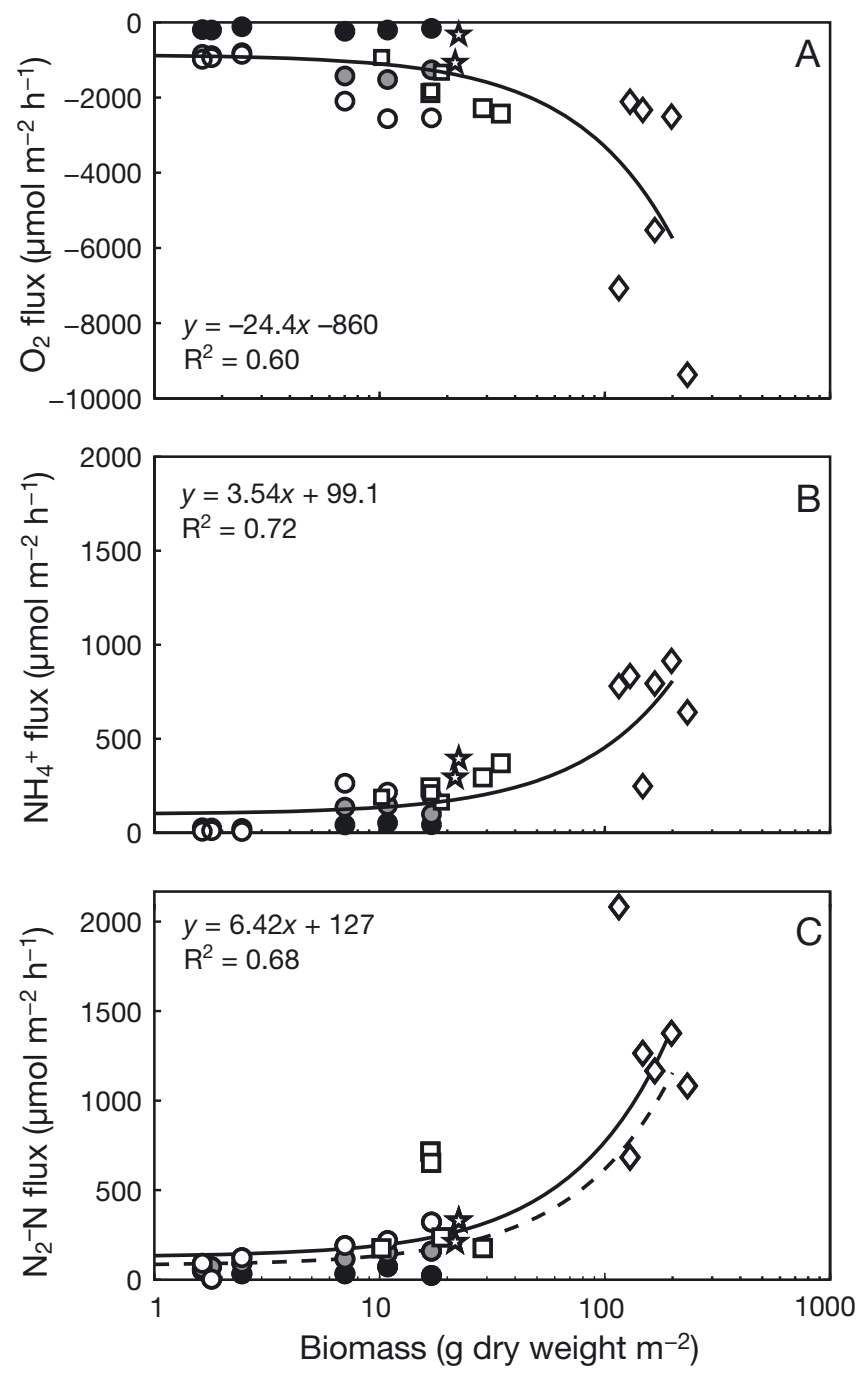

Fig. 5. Relationship between Alitta succinea biomass and sediment-water fluxes of (A) $\mathrm{O}_{2}$, (B) $\mathrm{NH}_{4}{ }^{+}$, and (C) $\mathrm{N}_{2}-\mathrm{N}$. Data points represent the biomasses and rates determined for the individual experimental units (cores with sediments and overlying water). Positive fluxes are out of the sediment and negative fluxes are into the sediment. Circles are data from the abundance-oxygen (A-O) experiment. Open symbols are for fluxes under Aerobic conditions, gray symbols are under transitional conditions, and black symbols are hypoxic conditions. The remainder symbols are data from the aerobic abundance-size (A-S) experiment, with squares representing fluxes for small worm treatments and diamonds for large worm treatments. Solid lines are linear regressions (equations given) on data from this study, and the dashed line in $(\mathrm{C})$ is for a previous published equation

(Bartoli et al. 2000)

relevant solutes, animal effects are often measured in terms of biomass. Macrofaunal biomass can be controlled experimentally by changing either density of animals or their average size. In this study we manipulate both metrics (density and size) to investigate impacts of polychaetes on $\mathrm{O}_{2}$ and nitrogen solute fluxes. Previous laboratory studies of nereid enhancement of solute fluxes reported results similar to ours, with relatively small densities and/or size of individuals in each treatment (Bartoli et al. 2000, Christensen et al. 2000, Swan et al. 2007). One of these studies (Bartoli et al. 2000) used A. succinea worms of a size similar to that used in our small worms treatment, and these authors found a remarkably similar linear relationship between animal biomass and denitrification (Fig. 5C). Our results indicated that the relationship also holds at higher worm biomass, suggesting a broader functional link between $\mathrm{N}_{2}$ flux and animal biomass (Fig. 5). The present study further revealed that sediment-water fluxes of $\mathrm{O}_{2}$ and $\mathrm{NH}_{4}{ }^{+}$were also significantly correlated to total $A$. succinea biomass (Fig. 5A,B), indicating that worm biomass is a general predictor of many sediment diagenetic processes. This result is consistent with previous reports for other nereid species (Henriksen 1980, Pelegri \& Blackburn 1995, Kristensen 2000, Nizzoli et al. 2007).

Macrofaunal body size is known to influence both physiological and behavioral processes (Ahrens \& Lopez 2001). By constructing deeper burrows, larger infauna ultimately increase advective and diffusive transport of key solutes (Kristensen \& Hansen 1999) and enhance rates and coupling of important redox reactions, including nitrification and denitrification. Deeper macrofaunal burrows effectively increase the area across which electron acceptors (e.g. $\mathrm{O}_{2}$ and $\mathrm{NO}_{3}$ ) and electron donors (e.g. $\mathrm{NH}_{4}{ }^{+}$and $\mathrm{S}^{2-}$ ) can readily diffuse between aerobic and anaerobic zones (Aller et al. 2001, Francois et al. 2001). This increased scope of bioirrigation by larger polychaetes is illustrated in our Expt A-S, where porewater profiles of $\mathrm{Br}$ and $\mathrm{NH}_{4}{ }^{+}$suggest that larger $A$. succinea transported these solutes from core sediment depths $>12 \mathrm{~cm}$, whereas the impact of smaller worms appears to have been confined to the upper $4 \mathrm{~cm}$ of sediments (Figs. 3 \& 4).

The present study also explored the potential importance of macrofaunal excretion rates and how these differed between our larger and smaller experimental animals (Table 2). Allometric relationships reflect the widely observed phenomenon that biomassspecific $\mathrm{NH}_{4}{ }^{+}$excretion tends to be higher for smaller animals (e.g. Kristensen 1984), and calculated rates were 0.9 and $0.4 \mu \mathrm{mol} \mathrm{g}{ }^{-1} \mathrm{~h}^{-1}$, respectively, for small and large worms (Table 2). Not surprisingly, larger individual worms had higher biomass and metabolic rates than did smaller ones, and thus per capita excretion rates were $>4$-fold higher for larger compared 
A) High-density large worm addition

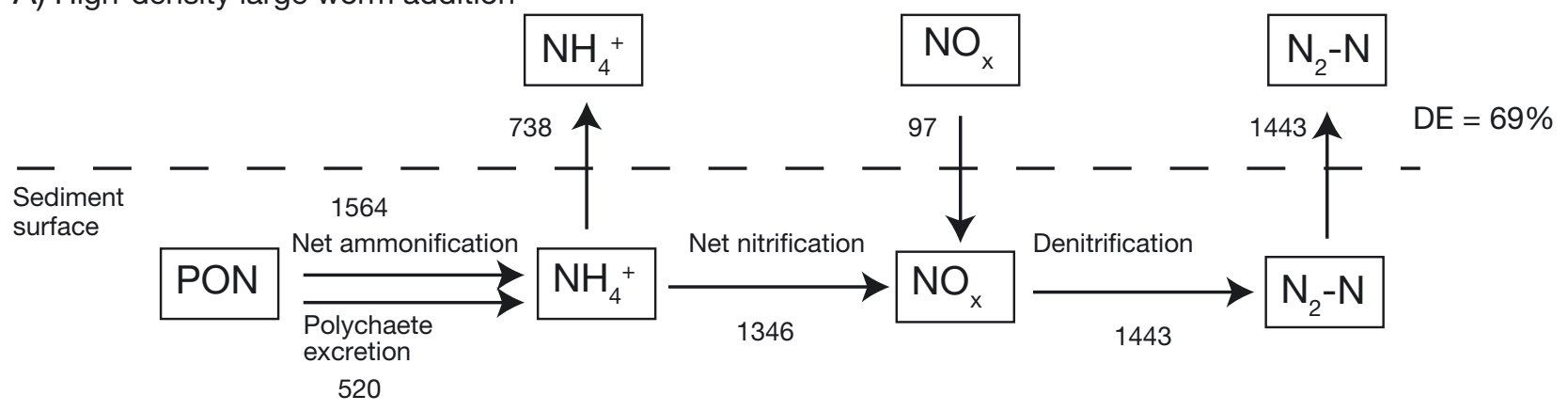

B) High-density small worm addition

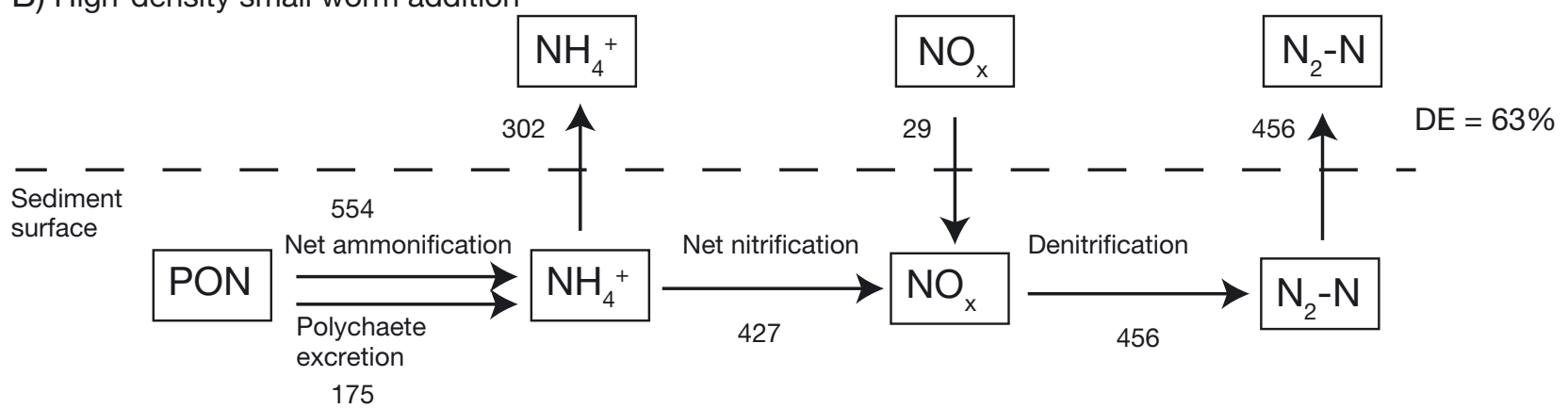

C) Control average

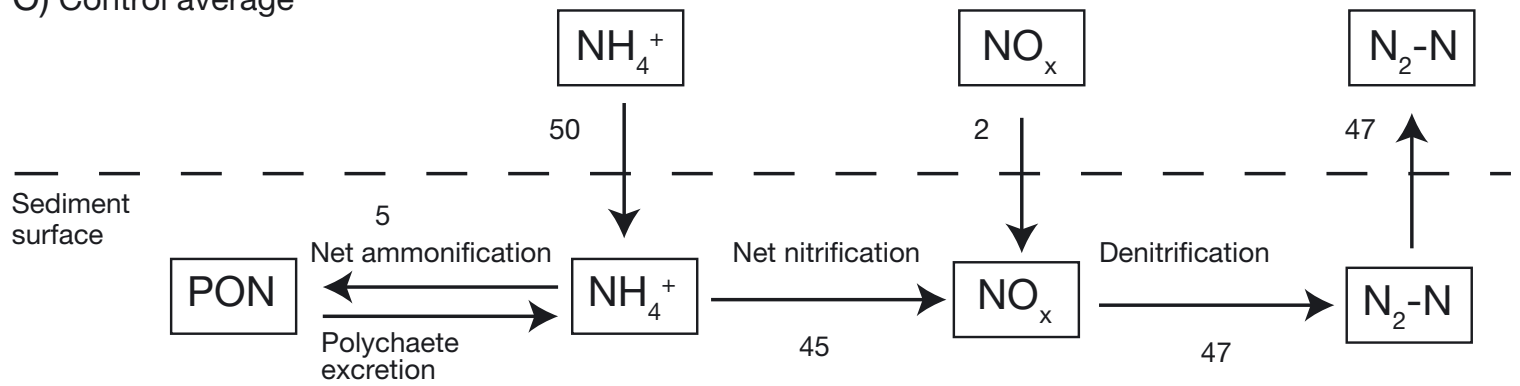

0

Fig. 6. Alitta succinea. Summary diagram with mean values of measured sediment-water fluxes, calculated polychaete $\mathrm{NH}_{4}{ }^{+}$ excretion fluxes (see Table 2) and mean calculated $\mathrm{N}$ transformation processes for net ammonification, net nitrification and denitrification. Here we assume steady-state mass-balance for arrows going to and from boxes (representing 3 porewater $\mathrm{N}$ pools), and we also assume that rates of dissimilatory nitrate reduction to ammonium and anammox are negligible (Tal et al. 2005, Rich et al. 2008, Giblin et al. 2013, Brin et al. 2014). Diagram compares mean fluxes and processes for (A) high-density large worm treatments, (B) high-density small worm treatments, and (C) control treatments for the abundance-size (A-S) experiment

to smaller worms (Table 2). The proportion of total $\mathrm{NH}_{4}{ }^{+}$effluxes comprised by excretion rates among our experimental treatments varied widely from $\sim 20$ to $70 \%$ (Table 2), which is considerably higher than the 10 to $40 \%$ range reported in previous works (Kristensen 1985, Boynton et al. 1997, Welsh 2003).

We further compared $\mathrm{NH}_{4}{ }^{+}$effluxes for small polychaete (high-density small worm) and large polychaete (1 large worm) treatments with similar worm biomass values of 166 and $194 \mathrm{~g}$ wet wt $\mathrm{m}^{-2}$, respectively (Table 2). As expected from Fig. 5B, rates of total $\mathrm{NH}_{4}{ }^{+}$effluxes for these 2 treatments were virtu- ally identical. Calculated rates $\left(\mathrm{m}^{-2}\right)$ for $\mathrm{NH}_{4}{ }^{+}$excretion for these 2 treatments were, however, 2.4 -fold higher for the 1 large worm treatment compared to the small worm treatment (Table 2). In addition, comparing our steady-state mass-balances for nitrogen fluxes in high-density treatments (Fig. 6) we see that, while $\mathrm{NH}_{4}{ }^{+}$effluxes were 2.4-fold higher for large worms than for small worms, respective rates of net nitrification and denitrification were even higher with large worms (5- and 4-fold, respectively). We speculate that higher rates of bio-irrigation by larger worms may have led to relatively higher advective 
fluxes of $\mathrm{NH}_{4}{ }^{+}$liberated from deep porewaters (e.g. Fig. 4). Thus, although the total biomass values and $\mathrm{NH}_{4}{ }^{+}$efflux rates were comparable for experimental cores with 1 large worm and 8 small worms, it appears that the relative rates of excretion, nitrification and bio-irrigation are directly related to worm size.

\section{Effects of oxygen limitation}

Effects of short-term, transient hypoxia in estuaries on benthic biogeochemical processes can be complex and difficult to predict (Weissberger et al. 2009). Depending on the timing and duration, hypoxic events may have a large impact on chemical equilibria, microbial activity, and macrofaunal physiology; however, effects may not be severe enough to kill off macrobenthic populations (Meyer-Reil \& Koster 2000). As $\mathrm{O}_{2}$ was depleted from the overlying water to below $94 \mu \mathrm{M} \mathrm{O}_{2}$, worms migrated closer to the surface, maintained their irrigation rates, but reduced burrow construction and ingestion (Long \& Seitz 2009). Once the overlying dissolved $\mathrm{O}_{2}$ reaches $63 \mu \mathrm{M} \mathrm{O} \mathrm{O}_{2}$ or lower, polychaetes stop constructing burrows, decrease their burrow ventilation and migrate closer to the sediment surface (Diaz \& Rosenberg 1995). Expt A-O data documents how these altered behaviors caused declines in sediment-water fluxes (Fig. 1).

As $\mathrm{O}_{2}$ declined in Expt A-O, each treatment underwent similar relative shifts in solute flux but at different rates. It is assumed that experimental cores did not reach steady-state in terms of solute flux over the brief duration of these experiments. The control and low-density treatments had relatively modest increases in $\mathrm{NH}_{4}{ }^{+}$flux as dissolved $\mathrm{O}_{2}$ decreased in each treatment core (Fig. 1B). $\mathrm{NO}_{\mathrm{x}}$ flux for lowdensity treatments also followed a pattern driven by concentration gradients, with an initial small efflux due to net nitrification under aerobic conditions, followed by a gradual decrease during transition, shifting to negative fluxes (driving denitrification) under hypoxia.

The high-density treatment, on the other hand, had a much greater relative $\mathrm{NH}_{4}{ }^{+}$efflux compared to the measured $\mathrm{NO}_{\mathrm{x}}$ influx, suggesting a strong bioirrigation effect. The significant decrease in $\mathrm{NH}_{4}{ }^{+}$efflux during transition from aerobic to hypoxic conditions within the high-density treatment cores implies marked reductions in worm metabolism, excretion and bioirrigation (Forbes \& Lopez 1990). The notable difference in denitrification rates with respect to high- and low-density treatments may also be attrib- uted to a change in large worm behavior. Under hypoxia, nereid worms are far more likely to be found on the sediment surface compared to under normal $\mathrm{O}_{2}$ conditions (Diaz 2001). Visual observations during Expt A-O revealed that as worms moved closer to the surface, their burrow depths became shallower and irrigation frequency declined, thus decreasing their vertical extent of influence on biogeochemical processes. During the transition period, when animals experience initial $\mathrm{O}_{2}$-limitation stress (Diaz \& Rosenberg 1995, Gray \& Elliott 2009), denitrification rates in Expt A-O remained elevated and significantly higher than in control treatments (Fig. 1D). However, the inability of $A$. succinea to continue stimulating denitrification under transitional and hypoxic conditions represents a pivotal impact on sediment nitrogen cycling. It appears that the precipitous decline of $\mathrm{O}_{2}, \mathrm{NH}_{4}{ }^{+}, \mathrm{NO}_{\mathrm{x}}$ and $\mathrm{N}_{2}$ fluxes across all treatments under hypoxic conditions resulted, in part, from a general down-shifting in polychaete metabolism as conditions degraded from aerobic to hypoxic (Gray \& Elliott 2009).

\section{Opportunistic polychaetes and ephemeral hypoxia}

Many studies have explored effects of infaunal bioturbation on organic matter diagenesis, and most of these studies structured experiments to allow infauna to equilibrate with their new surroundings prior to measurements (Henriksen et al. 1983, Kristensen 1984, Kristensen \& Blackburn 1987, Christensen et al. 2000). This approach tends to mimic longer-term macrofaunal effects under more stable conditions. Although many coastal systems commonly experience short-term hypoxic events, surprisingly little research has addressed the biogeochemical effects of macrofauna under these transient conditions (Bartoli et al. 2000, 2009, Nizzoli et al. 2007).

As for many estuaries, the increase of hypoxia in Chesapeake Bay has been attributed as a prime driver in an overall shift in benthic community structure, leading to reduced species diversity and biomass (Holland \& Diaz 1983, Dauer et al. 1992, Kemp et al. 2005). This bay community is now dominated by hypoxia-tolerant opportunistic species, like $A$. succinea, with seasonal cycles characterized by peak abundances in the spring and small resurgences in the late summer and fall (Llanso et al. 2010). Upon repopulating sediments in the spring, these small opportunistic worms can achieve high density due to limited competition for food resources (Gray et al. 2002). Their tolerance for short-term hypoxic events, 
however, makes these polychaetes important players in spring and early summer remineralization of organic material in this system.

As shown in previous work (Kristensen \& Blackburn 1987, Pelegri \& Blackburn 1995, Bartoli et al. 2000, Marinelli \& Williams 2003, Welsh 2003, Braeckman et al. 2010), our study demonstrates that polychaete enhancement of net sediment-water fluxes is linked to total polychaete biomass. This study also supports the hypothesis that effects of macrofauna on these fluxes decline as overlying water $\mathrm{O}_{2}$ levels decrease to hypoxic levels. Our experiments further explain effects of worm size on sediment biogeochemical processes. Compared to small polychaetes, larger animals burrow deeper in sediments, irrigate greater volumes of water and solutes through these burrows, but excrete less per biomass. These attributes of larger worms tend to enhance rates of sediment nitrification and denitrification, effectively helping to remove fixed-nitrogen from nutrient-rich environments. However, smaller opportunistic worms with less pronounced stimulation of denitrification often dominate eutrophic systems that regularly experience low $\mathrm{O}_{2}$ conditions. Thus, the hypoxia-induced shift from larger to smaller polychaetes, and the associated decline in nitrification and denitrification rates, represents a 'positive feedback' process whereby high nutrient levels stimulate low $\mathrm{O}_{2}$, which selects for smaller polychaetes that stimulate efficient nitrogen recycling, which in turn reinforces the eutrophication process (Kemp et al. 2005, Conley et al. 2007).

Acknowledgements. We thank Michael Owens, Debbie Hinkle and Elgin Perry for their assistance in collection, data processing and statistical analysis. Insightful discussions with dissertation committee members Walter Boynton, Dominic Di Toro and Jacqueline Grebmeier were valuable in the formulation of our ideas. Comments from 3 anonymous reviewers were very helpful in guiding the revision from an earlier draft. Horn Point Laboratory Graduate Research Fellowship, a graduate student scholarship from the Isaac Walton League of America (Talbot County Chapter), and the US Department of Commerce, National Oceanographic and Atmospheric Administration grant NA07- NOS4780191 provided funding for this work.

\section{LITERATURE CITED}

Ahrens MJ, Lopez GR (2001) In vivo characterizartion of the gut chemistry of small deposit-feeding polychaetes. In: Aller JY, Woodin SA, Aller RC (eds) Organism-sediment interactions. University of South Carolina Press, Columbia, SC, p 349-368

Aller RC (1994) Bioturbation and remineralization of sedimentary organic-matter: effects of redox oscillation.
Chem Geol 114:331-345

Aller RC, Aller J, Kemp P (2001) Effects of particle and solute transport on rates and extent of remineralization in bioturbated sediments. In: Aller JY, Woodin SA, Aller RC (eds) Organism-sediment interactions. University of South Carolina Press, Columbia, SC, p 315-332

An SM, Gardner WS, Kana T (2001) Simultaneous measurement of denitrification and nitrogen fixation using isotope pairing with membrane inlet mass spectrometry analysis. Appl Env Microbiol 67:1171-1178

Bartoli M, Nizzoli D, Welsh DT, Viaroli P (2000) Short-term influence of recolonisation by the polycheate worm Nereis succinea on oxygen and nitrogen fluxes and denitrification: a microcosm simulation. Hydrobiologia 431: 165-174

Bartoli M, Longhi D, Nizzoli D, Como S, Magni P, Viaroli P (2009) Short term effects of hypoxia and bioturbation on solute fluxes, denitrification and buffering capacity in a shallow dystrophic pond. J Exp Mar Biol Ecol 381: 105-113

Bianchi TS (2007) Biogeochemistry of estuaries. Oxford University Press, New York, NY

Boudreau BP (1996) The diffusive tortuosity of fine-grained unlithified sediments. Geochim Cosmochim Acta 60: 3139-3142

Boynton WR, Magdeburger LL, Weaver BJ, Barne JM (1997) The effects of macrobenthos on sediment-water oxygen and ammonium fluxes. Univeristy of Maryland System. Center for Environmental and Estuarine Studies, Chesapeake Biological Laboratory, Solomons, MD

Braeckman U, Provoost P, Gribsholt B, Van Gansbeke D and others (2010) Role of macrofauna functional traits and density in biogeochemical fluxes and bioturbation. Mar Ecol Prog Ser 399:173-186

Brin LD, Giblin AE, Rich JJ (2014) Environmental controls of anammox and denitrification in southern New England estuarine and shelf sediments. Limnol Oceanogr 59: 851-860

Christensen B, Vedel A, Kristensen E (2000) Carbon and nitrogen fluxes in sediment inhabited by suspensionfeeding (Nereis diversicolor) and non-suspensionfeeding ( $N$. virens) polychaetes. Mar Ecol Prog Ser 192: 203-217

Conley DJ, Carstensen J, Ertebjerg G, Christensen PB, Dalsgaard T, Hansen JLS, Josefson AB (2007) Long-term changes and impacts of hypoxia in Danish coastal waters. Ecol Appl 17:S165-S184

> Dauer DM, Rodi AJ, Ranasinghe J (1992) Effects of low dissolved oxygen events on the macrobenthos of the lower Chesapeake Bay. Estuaries 15:384-391

Diaz RJ, Rosenberg R (1995) Marine benthic hypoxia: a review of its ecological effects and the behavioural responses of benthic macrofauna. Oceanogr Mar Biol Annu Rev 33:245-303

- Diaz RJ, Rosenberg R (2008) Spreading dead zones and consequences for marine ecosystems. Science 321:926-929

Diaz R, Cutter GR Jr (2001) In situ measurement of organism-sediment interaction: rates of burrow formation, abandonment and sediment oxidation, reduction. In: Aller JY, Woodin SA, Aller RC (eds) Organism-sediment interactions. University of South Carolina Press, Columbia, SC, p 19-86

Fauchald K, Jumars PA (1979) The diet of worms: a study of polychaete feeding guilds. Oceanogr Mar Biol Annu Rev $17: 193-284$ 
Fisher TR, Hagy JD, Boynton WR, Williams MR (2006) Cultural eutrophication in the Choptank and Patuxent estuaries of Chesapeake Bay. Limnol Oceanogr 51:435-447

Forbes TL, Lopez GR (1990) The effect of food concentration, body size, and environmental oxygen-tension on the growth of the deposit-feeding polychaete, Capitella species 1. Limnol Oceanogr 35:1535-1544

Francois F, Poggiale J, Durbec J, Stora G (2001) A new model of bioturbation for a functional approach to sediment reworking resulting from macrobenthic communities. In: Aller JY, Woodin SA, Aller RC (eds) Organismsediment interactions. University of South Carolina Press, Columbia, SC, p 73-86

Giblin AE, Tobias CR, Song B, Weston N, Banta GT, RiveraMonroy VH (2013) The importance of dissimilatory nitrate reduction to ammonium (DNRA) in the nitrogen cycle of coastal ecosystems. Oceanography (Wash DC) 26:124-131

Gray JS, Elliott M (2009) Ecology of marine sediments: from science to management. Oxford University Press, New York, NY

> Gray JS, Wu RSS, Or YY (2002) Effects of hypoxia and organic enrichment on the coastal marine environment. Mar Ecol Prog Ser 238:249-279

Henriksen K, Kemp WM (1988) Nitrification in estuarine and coastal marine sediments. In: Blackburn TH, Sorensen J (eds) Nitrogen cycling in coastal marine environments. John Wiley \& Sons, New York, NY, p 207-249

Henriksen K, Hansen JI, Blackburn TH (1980) The influence of benthic infauna on exchange rates of inorganic nitrogen between sediment and water. Ophelia Suppl 1:249-256

Henriksen K, Rasmussen MB, Jensen A (1983) Effect of bioturbation on microbial nitrogen transformations in the sediment and fluxes of ammonium and nitrate to the overlaying water. Ecol Bull 35:193-205

Holland AF, Diaz RJ (1983) Long-term trends in the infauna of Chesapeake Bay and their relationship to changes in conditions. Estuaries 6:328-329

Holland AF, Shaughnessy AT, Hiegel MH (1987) Long-term variation in mesohaline Chesapeake Bay macrobenthos: spatial and temporal patterns. Estuaries 10:227-245

> Jørgensen NOG, Kristensen E (1980) Uptake of amino acids by three species of Nereis (Annelida: Polychaeta). II. Effects of anaerobiosis. Mar Ecol Prog Ser 3:341-346

Kana TM, Darkangelo C, Hunt MD, Oldham JB, Bennett GE, Cornwell JC (1994) Membrane inlet mass-spectrometer for rapid high-precision determination of $\mathrm{N}_{2}, \mathrm{O}_{2}$, and $\mathrm{Ar}$ in environmental water samples. Anal Chem 66: 4166-4170

Kana TM, Cornwell JC, Zhong LJ (2006) Determination of denitrification in the Chesapeake Bay from measurements of $\mathrm{N}_{2}$ accumulation in bottom water. Estuaries Coasts 29:222-231

Kellogg M, Cornwell J, Owens M, Paynter K (2013) Denitrification and nutrient assimilation on a restored oyster reef. Mar Ecol Prog Ser 480:1-19

Kellogg ML, Smyth AR, Luckenbach MW, Carmichael RH and others (2014) Use of oysters to mitigate eutrophication in coastal waters. Estuar Coast Shelf Sci 151:156-168

Kemp WM, Boynton WR, Adolf JE, Boesch DF and others (2005) Eutrophication of Chesapeake Bay: historical trends and ecological interactions. Mar Ecol Prog Ser 303:1-29

Kristensen E (1983a) Ventilation and oxygen-uptake by three species of Nereis (Annelida: Polychaeta). I. Effects of hypoxia. Mar Ecol Prog Ser 12:289-297

- Kristensen E (1983b) Ventilation and oxygen-uptake by three species of Nereis (Annelida: Polychaeta). II. Effects of temperature and salinity changes. Mar Ecol Prog Ser 12:299-305

Kristensen E (1984) Effect of natural concentrations on nutrient exchange between a polychaete burrow in estuarine sediment and the overlying water. J Exp Mar Biol Ecol 75:171-190

Kristensen E (1985) Oxygen and inorganic nitrogen exchange in a Nereis virens (Polychaeta) bioturbated sediment-water system. J Coast Res 1:109-116

> Kristensen E (2000) Organic matter diagenesis at the oxic/ anoxic interface in coastal marine sediments, with emphasis on the role of burrowing animals. Hydrobiologia 426:1-24

Kristensen K, Hansen K (1999) Transport of carbon dioxide and ammonium in bioturbated (Nereis diversicolor) coastal, marine sediments. Biogeochemistry 45:147-168

Kristensen E, Kostka JE (2005) Macrofaunal burrows and irrigation in marine sediment: microbiological and biogeochemical interactions. In: Kristensen E, Haese RR, Kostka JE (eds) Interactions between macro- and microorganisms in marine sediments. American Geophysical Union, Washington, DC, p 125-157

Kristensen E, Penha-Lopes G, Delefosse M, Valdemarsen T, Quintana CO, Banta GT (2012) What is bioturbation? The need for a precise definition for fauna in aquatic sciences. Mar Ecol Prog Ser 446:285-302

Kristensen E, Blackburn TH (1987) The fate of organic carbon and nitrogen in experimental marine sediment systems: influence of bioturbation and anoxia. J Mar Res 45:231-257

Llanso RJ, Scott LC, Dauer DM, Hyland JL, Russell DE (2002) An estuarine benthic index of biotic integrity for the MidAtlantic region of the United States. I. Classification of assemblages and habitat definition. Estuaries 25:1219-1230

Llanso RJ, Dew-Baxter J, Scott LC (2010) Chesapeake Bay water quality monitoring program. Long-term benthic monitoring and assessment component Level 1 comprehensive report, July 1984-December 2009 (Volume 1). Versar, Columbia, MD

> Long WC, Seitz RD (2009) Hypoxia in Chesapeake Bay tributaries: worsening effects on macrobenthic community structure in the York River. Estuaries Coasts 32:287-297

- Marinelli RL, Williams TJ (2003) Evidence for densitydependent effects of infauna on sediment biogeochemistry and benthic-pelagic coupling in nearshore systems. Estuar Coast Shelf Sci 57:179-192

> Meyer-Reil LA, Koster M (2000) Eutrophication of marine waters: effects on benthic microbial communities. Mar Pollut Bull 41:255-263

> Meysman FJR, Middelburg JJ, Heip CHR (2006) Bioturbation: a fresh look at Darwin's last idea. Trends Ecol Evol 21:688-695

> Miron G, Kristensen E (1993) Factors influencing the distribution of nereid polychaetes: the sulfide aspect. Mar Ecol Prog Ser 93:143-153

Nizzoli D, Bartoli M, Cooper M, Welsh DT, Underwood GJC, Viaroli P (2007) Implications for oxygen, nutrient fluxes and denitrification rates during the early stage of sediment colonisation by the polychaete Nereis spp. in four estuaries. Estuar Coast Shelf Sci 75:125-134

Officer CB, Biggs RB, Taft JL, Cronin LE, Tyler MA, Boynton WR (1984) Chesapeake Bay anoxia: origin, development, 
and significance. Science 223:22-27

Papaspyrou S, Gregersen T, Kristensen E, Christensen B, Cox RP (2006) Microbial reaction rates and bacterial communities in sediment surrounding burrows of two nereidid polychaetes (Nereis diversicolor and $N$. virens). Mar Biol 148:541-550

Parsons TR, Maita Y, Lalli CM (1984) A manual of chemical and biological methods for seawater analysis. Pergamon Press, Oxford

Pelegri SP, Blackburn TH (1995) Effect of bioturbation by Nereis sp, Mya arenaria and Cerastoderma sp. on nitrification and denitrification in estuarine sediments. Ophelia 42:289-299

Porter ET, Owens MS, Cornwell JC (2006) Effect of sediment manipulation on the biogeochemistry of experimental sediment systems. J Coast Res 22:1539-1551

Rich JJ, Dale OR, Song B, Ward BB (2008) Anaerobic ammonium oxidation (Anammox) in Chesapeake Bay sediments. Microb Ecol 55:311-320

Schaffner LC, Dellapenna TM, Hinchey EK, Friedrich CT, Neubauer MT, Smith ME, Kuehl SA (2001) Physical energy regimes, seabed dynamics, and organism-sedi-

Editorial responsibility: Erik Kristensen,

Odense, Denmark ment interactions along an estuarine gradient. In: Aller JY, Woodin SA, Aller RC (eds) Organism-sediment interactions. University of South Carolina Press, Columbia, SC, p 159-178

Swan BK, Watts JM, Reifel KM, Hurlbert SH (2007) Role of the polychaete Neanthes succinea in phosphorus regeneration from sediments in the Salton Sea, California. Hydrobiologia 576:111-125

> Tal Y, Watts JEM, Schreier HJ (2005) Anaerobic ammoniaoxidizing bacteria and related activity in Baltimore inner harbor sediment. Appl Environ Microbiol 71:1816-1821

> Weissberger EJ, Coiro LL, Davey EW (2009) Effects of hypoxia on animal burrow construction and consequent effects on sediment redox profiles. J Exp Mar Biol Ecol 371:60-67

Welsh DT (2003) It's a dirty job but someone has to do it: the role of marine benthic macrofauna in organic matter turnover and nutrient recycling to the water column. Chem Ecol 19:321-342

Yuan-Hui L, Gregory S (1974) Diffusion of ions in sea water and in deep-sea sediments. Geochim Cosmochim Acta 38:703-714

Submitted: October 28, 2013; Accepted: December 22, 2014 Proofs received from author(s): March 16, 2015 